Sciences

Vol. 07, No. 01, pp. 81-93, March 2014

\title{
SECONDARY ARC EXTINCTION IN EXTRA HIGH VOLTAGE SYSTEMS USING GROUNDING SWITCHES
}

\author{
Qais M. Alias ${ }^{1}$, Wafaa F. Tobia ${ }^{2}$ \\ ${ }^{1}$ Lecturer, ${ }^{2}$ Asst. Lecturer, Department of Electrical Engineering \\ University of Technology, Iraq \\ E-mail: qaismatti2004@yahoo.com ${ }^{1}$, umfarah2005@yahoo.com ${ }^{2}$ \\ (Received: 31/12/2012; Accepted: 24/3/2013)
}

\begin{abstract}
Long Extra High Voltage (EHV) transmission systems tend to bring a pronounced state of secondary arcing. Therefore, an essential pre-requisite for single-phaseswitching application, is the possibility and speed of secondary arc final extinction during suitably short dead-time. During the past several decades, many techniques had been proposed and implemented in order to ensure fast secondary arc extinction. Among these was the use of High Speed Grounding Switches (HSGS's). In such technique, the faulted phase is grounded via special switches; one at each end of the EHV line after the fault is cleared by both line ends circuit breakers. The primary advantage of grounding the faulted phase is the reduction of the fault point recovery voltage to a very low value. This, coupled with the circulation of opposite loop currents in the fault path, reduces the secondary arc current and lead to a fast secondary arc extinction. A sample $500 \mathrm{kV}, 300 \mathrm{~km}$ transmission system equipped with High Speed Grounding Switches is modeled as a test system. The modified Fourier transform is used to calculate the system response through, fault, fault clearance, HSGS's operation, and line restoration. The non-linearity of the secondary arcing state is also accounted for. The paper concludes with a presentation of some computational results related to the above mentioned EHV system showing that HSGS's greatly improves the singlephase-switching performance.
\end{abstract}

Keywords: Single-phase-switching, secondary arc, high speed grounding switches.

\section{LIST of PRINCIPAL SYMBOLS}

$\mathrm{a}, \mathrm{b}, \mathrm{c}=$ Phases $\mathrm{a}, \mathrm{b}, \mathrm{c}$.

$\mathrm{A}_{\mathrm{L}}, \mathrm{B}_{\mathrm{L}}, \mathrm{C}_{\mathrm{L}}, \mathrm{D}_{\mathrm{L}}$

$\left.A_{R}, B_{R}, C_{R}, D_{R}\right\}=$ Matrices of the line sections linking the fault point to both line ends.

$\mathrm{E}_{\mathrm{a}}, \mathrm{E}_{\mathrm{b}}, \mathrm{E}_{\mathrm{c}}=$ Nominal phase-to-neutral voltages.

$\bar{E}_{F K}, \bar{E}_{S K}, \bar{E}_{R K}=$ Transforms of voltages at fault, send and receive ends respectively. 
$\bar{E}_{S g K}, \bar{E}_{R g K}=$ Transforms of voltages to neutral at the HSGS at send and receive ends respectively.

$\mathrm{h}\left(\mathrm{t}-\mathrm{T}_{\mathrm{e}}\right)=$ Delayed unit step function,

$=0$ for $\mathrm{t}<\mathrm{T}_{\mathrm{e}}$, and,

$=1$ for $\mathrm{t}>\mathrm{T}_{\mathrm{e}}$.

$\mathrm{F}=$ Fault point.

$\mathrm{I}_{\mathrm{P}}=$ Secondary arc cyclogram current parameter.

$\left|I_{S}\right|=$ Nominal steady-state value of secondary arc current.

$\bar{I}_{F K}, \bar{I}_{F S K}, \bar{I}_{F R K}=$ Transforms of superimposed currents at the fault point.

$\bar{I}_{S g K}, \bar{I}_{R g K}=$ Transforms of superimposed currents at the send and receive ends HSGS respectively.

$\bar{I}_{S K}, \bar{I}_{R K}=$ Transforms of superimposed currents at the send and receive ends respectively.

$\mathrm{K}=$ Subscripts denotes switching event-K.

$\mathrm{L}(\mathrm{t}) / \mathrm{L}_{\mathrm{o}}=$ Per unit arc length variation.

$\mathrm{t}=$ Any time $\mathrm{t}$.

$\mathrm{T}_{\mathrm{e}}=$ Secondary arc extinction time, (measured from time of initiation of secondary arc).

$\bar{V}_{F K}, \bar{V}_{S K}, \bar{V}_{R K}=$ Transforms of superimposed voltages at the fault, send, and receive ends respectively.

$\mathrm{V}_{\mathrm{P}}=$ Secondary arc cyclogram voltage parameter.

$\mathrm{Z}_{\mathrm{so}} / \mathrm{Z}_{\mathrm{s} 1}=$ Ratio of zero phase sequence to positive phase sequence impedances of source.

$\mathrm{Z}_{\mathrm{SS}}, \mathrm{Z}_{\mathrm{SR}}=$ Send and receive ends source impedance matrices.

a.f. $=$ After fault

\section{INTRODUCTION}

The increasing financial and environmental constraints that electric utilities facing, necessitate a slow expansion in the transmission facilities. Three-Phase-Switching (TPS) was and still is being used by numerous utilities as a means of clearing any type of fault occurring on the transmission system. TPS use is justified by, the simple relaying, conventional circuitbreaker design, and very high possibility of fast arc extinction to facilitate subsequent system restoration. Recognizing that a high percentage of line faults are single-phase-to-earth and temporary in nature, promotes considering Single-Phase-Switching (SPS) for application as a means to enhance system stability and security ${ }^{(1)}$. The effectiveness of SPS schemes is largely determined by the speed with which the secondary arcs extinguish, and hence, allow reclosure and system restoration. 
When a single-phase-to-earth fault is isolated by SPS, the arc cannot be immediately vanished. That is because of the inductive and capacitive couplings of the switched- phase with the sound-phases. As such, a relatively low secondary arc current is maintained through the primary, highly ionized fault path ${ }^{(2,3)}$. Upon temporal or final extinction of the secondary arc, the sound-phases determine the restriking voltage transients, i.e. the fault-point recovery voltage.

Long extra high voltage untransposed lines are characterized by significant discrepancies in inter-phases coupling parameters (inductive and capacitive). Such discrepancies nominated the use of special treatment schemes for SPS application. Among these, the switched reactor compensation ${ }^{(4)}$, the hybrid scheme ${ }^{(5)}$, and the High Speed Grounding Switches (HSGS's) scheme ${ }^{(6)}$.

In this work, the modified Fourier transform is used in the calculation of the system response throughout the switching operations ${ }^{(7)}$. Starting at fault inception, end breakers opening (isolating the faulty phase and transfer to the secondary arcing state), HSGS's closing and then opening after arc extinction, finally end breakers closing and system restoration. The arc nonlinearity is dealt with using the arc model developed in ${ }^{(7)}$. Extensive series of digital simulation studies have been performed on a $300 \mathrm{~km}$ long, untransposed, $500 \mathrm{kV}$ line.

\section{THE SECONDARY ARC MODEL}

The net coupling between faulty and sound phases that maintain the secondary arc depends, principally, on line construction, line length, prefault loading, and the degree of compensation (if present). Johns et. al. ${ }^{(7,8)}$ concluded that the secondary arc current extinction and reignition at each current zero crossing continues as long as the system recovery voltage at the fault-point is higher than the arc voltage. The conduction is represented by a piece-wise voltage-current linearized cyclogram in which both $i_{\text {arc }}(t)$ and $V_{\text {arc }}(t)$ are functions of the arc peak current $I_{P}$. $I_{P}$ is obtained from a steady-state simple calculation. Figure (1) shows the $i_{\text {arc }}, V_{\text {arc }}$ cyclogram.Using the data obtained from experimental staged fault tests, Johns et. al. ${ }^{(7,8)}$ proposed the use of eq. (1) for the arc length versus time variation and given as;

$\left.\begin{array}{l}\mathrm{L}(\mathrm{t}) / \mathrm{L}_{\mathrm{o}}=1, \text { for } \mathrm{t} \leq 0.1 \mathrm{sec} \\ \mathrm{L}(\mathrm{t}) / \mathrm{L}_{\mathrm{o}}=10 \mathrm{t} \text { for } \mathrm{t}>0.1 \mathrm{sec}\end{array}\right\}$

Additionally, from field test results simulation, Johns et. al. proposed the reignition voltage characteristic relation given by eq. (2), with values in $10^{5} \mathrm{~V} / \mathrm{m}$.

$\mathrm{v}_{\mathrm{r}}(\mathrm{t})=\left(5+1620 \mathrm{~T}_{\mathrm{e}} /\left(2.15+\mathrm{I}_{\mathrm{s}}\right)\right)\left(\mathrm{t}-\mathrm{T}_{\mathrm{e}}\right) \mathrm{h}\left(\mathrm{t}-\mathrm{T}_{\mathrm{e}}\right)$ 


\section{THE SYSTEM SIMULATION}

Modern EHV transmission lines are not usually transposed resulting in unsymmetrical couplings. This is more pronounced in the horizontal disposition of line conductor's configuration. Figure (2) shows a general PI-section lumped parameter representation of a three-phase transmission line where the notation are self-explanatory. For simplicity, ignoring all lossy and inductive elements, Figure (2) can be reduced to that of Figure (3). In Figure (3), for a single-phase-to-earth fault, the secondary arc current and recovery voltage are easily found for each phase as per eq.'s (3), (4):

$$
\left.\begin{array}{l}
I_{\text {seca }}=j \omega_{o}\left(C_{a b} E_{b}+C_{a c} E_{c}\right) \\
I_{\text {secb }}=j \omega_{o}\left(C_{a b} E_{a}+C_{b c} E_{c}\right) \\
I_{s e c c}=j \omega_{o}\left(C_{a c} E_{a}+C_{b c} E_{b}\right)
\end{array}\right\}
$$

And;

$$
\left.\begin{array}{l}
\mathrm{V}_{\mathrm{ra}}=\frac{\mathrm{C}_{\mathrm{ab}} \mathrm{E}_{\mathrm{b}}+\mathrm{C}_{\mathrm{ac}} \mathrm{E}_{\mathrm{c}}}{\mathrm{C}_{\mathrm{ab}}+\mathrm{C}_{\mathrm{ac}}+\mathrm{C}_{\mathrm{ag}}} \\
\mathrm{V}_{\mathrm{rb}}=\frac{\mathrm{C}_{a b} E_{a}+C_{b c} E_{c}}{\mathrm{C}_{\mathrm{ab}}+\mathrm{C}_{\mathrm{bc}}+\mathrm{C}_{\mathrm{bg}}} \\
\mathrm{V}_{\mathrm{rc}}=\frac{\mathrm{C}_{\mathrm{ac}} \mathrm{E}_{\mathrm{a}}+\mathrm{C}_{\mathrm{bc}} \mathrm{E}_{\mathrm{b}}}{\mathrm{C}_{\mathrm{ac}}+\mathrm{C}_{\mathrm{bc}}+\mathrm{C}_{\mathrm{cg}}}
\end{array}\right\}
$$

In power systems, transmission lines are energized from source networks whose configurations and characteristics vary widely. In this work a general source model based on arbitrary defined short circuit level at the terminating bus is used ${ }^{(7)}$, and of the diagram shown in Figure (4). The general source impedance matrix of the form given in eq. (5) can be derived based on the given short circuit level and, the source $\mathrm{x} / \mathrm{r}$ ratio at power frequency, the $\mathrm{Z}_{\mathrm{so}} / \mathrm{Z}_{\mathrm{s} 1}$ ratio, and the system line voltage.

$\mathrm{Z}_{\mathrm{ss}}=\left[\begin{array}{ccc}Z_{s 1}+Z_{n 1} & Z_{n 1} & Z_{n 1} \\ Z_{n 1} & Z_{s 1}+Z_{n 1} & Z_{n 1} \\ Z_{n 1} & Z_{n 1} & Z_{s 1}+Z_{n 1}\end{array}\right]$

System simulation from time of fault inception to that of system restoration involves a large number of time discontinuities. Such nonlinearities are dealt with using the modified Fourier transform techniques ${ }^{(8)}$. Mathematically speaking, opening or closing of a switch (discontinuity) is done by injecting equal opposite current or equal opposite voltage respectively at the point of discontinuity. 
The fault inception, the faulted-phase opening (start of secondary arcing), the HSGS's closure, the secondary arc current extinction, the opening of the HSGS's, and finally the breaker restoration of the faulted-phase, this is the sequence of events to be considered in a complete autoreclosure study. The system under normal operating conditions comprising the side's source and the line under study is shown in block form in Figure (5). The full system frequency domain superimposed model is shown in Figure (6).

\section{SYSTEM CASE STUDY}

The computational results to be presented in this work are for $500 \mathrm{kV}$, single circuit, untransposed transmission line system. Figure (7) shows the typical quad-conductor line configuration. The data for the line, end source, HSGS's, and Fourier transform parameters are:

Phase-conductor-4*477MCM, AL-alloy, $2.15 \mathrm{~mm}$ overall, $242 \mathrm{~mm}^{2}$ AL- equivalent, 19/4.3mm stranding.

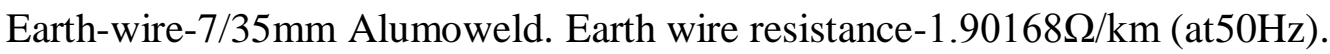

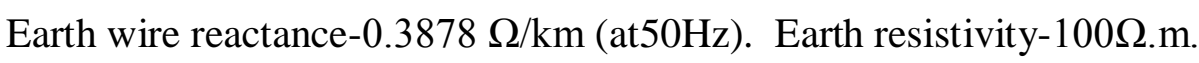

Conductor resistence- $0.02175 \Omega / \mathrm{km}$ (at50Hz). Conductor reactance- $0.0038 \Omega / \mathrm{km}$ (at $50 \mathrm{~Hz})$

Line length-300km. Distance between arcing horns-4.05m.

The impedance matrix of each line end source has been formulated based on:

Line ends short circuit level=5 to 10GVA.

Source $\mathrm{x} / \mathrm{r}$ ratio at $50 \mathrm{~Hz}=100$.

Source $\mathrm{Z}_{\mathrm{so}} / \mathrm{Z}_{\mathrm{s} 1}$ ratio $=0.5$ to 1.0 .

The HSGS's parameters are:

HSGS closing-time $=10$ cycles after fault inception. HSGS opening-time $=20$ cycles after fault inception. The HSGS resistance $=0.5$ to $10 \Omega$ 's.

The modified Fourier transform parameters are:

Observation time $=0.8192 \mathrm{sec}$. Frequency shift constant $=7.67$. Number of samples $=4096$.

Truncation frequency $=2.5 \mathrm{kHz}$.

\section{SIMULATION RESULTS}

The system mathematical formulation as briefly developed in the past sections is used to obtain the system transient behavior. The response through all-time intervals i.e. primary fault, fault isolation and secondary arcing, HSGS's closure, arc extinction, HSGS's opening and final system restoration are superimposed to obtain the full system behavior. Factors like, fault location, pre-fault loading, terminal station parameters and those of the HSGS's 
were considered to analyze their effect on system performance and on the secondary arc extinction. The program compact flowchart adopted throughout this study is shown in Fig. (8).

Sample output results are presented in Fig's.9, 10, and 11. The system condition and parameters are given accompanied the figures. Figure (12) shows the negligible effect of the HSGS resistance when in the $0.5-100 \Omega$ range on the secondary arc extinction time. Extensive series of simulation studies were performed and next section presents the general conclusions reached.

\section{CONCLUSIONS}

Successful single-phase-switching depends on rapid arc extinction, which can be provided for by grounding the faulted phase at both ends. The use of HSGS's proved effective in extinguishing the secondary arcs in the untransposed line EHV systems. For the $300 \mathrm{~km}$ line considered here, the arc extinguished within one-half cycle after the HSGS's closure irrespective of the pre-fault flow and fault position. Also, it was noticed that the source-side parameters do not affect the arc extinction time or the HSGS current. The results obtained are in good agreement with practical system fault test results reported in [Hasibar et al. $\left.{ }^{(6)}\right]$.

\section{REFERENCES}

1- IEEE Committee Report, (1992), "Single phase tripping and auto reclosing of transmission lines", Trans. on Power Delivery, Vol.7, No.1.

2- Kimbark, E.W., (1976), "Selective-pole switching of long double-circuit EHV lines", IEEE Trans., PAS-95, No.1.

3- Yu Lin, and Jun Wen, (2009), "Simulation analysis of single-phase adaptive autoreclose on UHV transmission lines with shunt reactors", International Conf. on Energy and Environment Technology, IEEE.

4- Shperling, B.R., and Fakheri, A., (1979), "Single-phase switching parameters for untransposed EHV lines", IEEE Trans., PAS-98, No.2.

5- Alias, Q.M., (1998), "Digital simulation of the hybrid technique in EHV long transmission systems", Engineering \& Technology Journal, Vol.17, No.1.

6- Hasibar, R.M., Legate, A.C., Brunke, J. and Peterson, W.G., (1981), “The application of high-speed grounding switches for single-phase reclosing on $500 \mathrm{kV}$ power systems", IEEE Trans., PAS-100, No.4. 
7- Johns, A.T. and Al-Rawi, A.M., (1982), "Digital simulation of EHV systems under secondary arcing conditions associated with single-pole autoreclosure", IEE Proc. Pt. C., Vol.129, No.2.

8- Johns, A.T. and Al-Rawi, A.M. (1984), "Developments in the simulation of long distance single-pole switched EHV systems", IEE Proc. Pt. C., Vol.131, No.2.

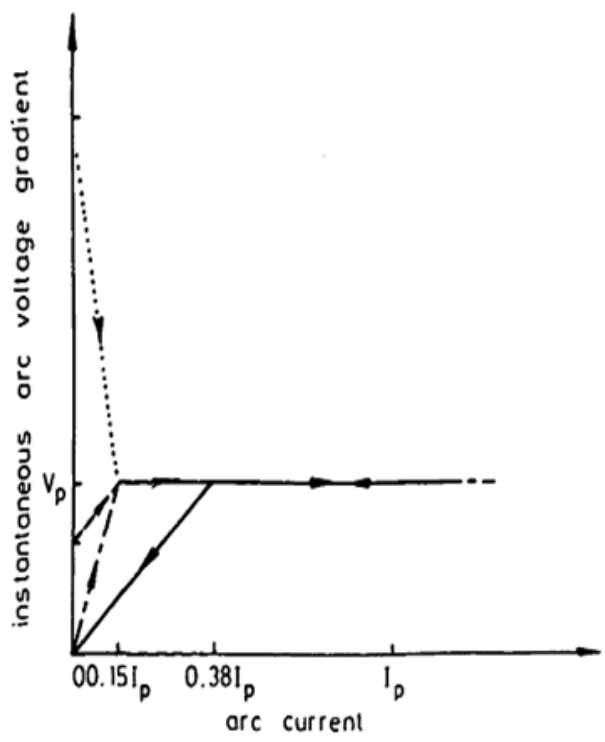

Figure (1): Piece-wise linearized secondary arc cyclogram.

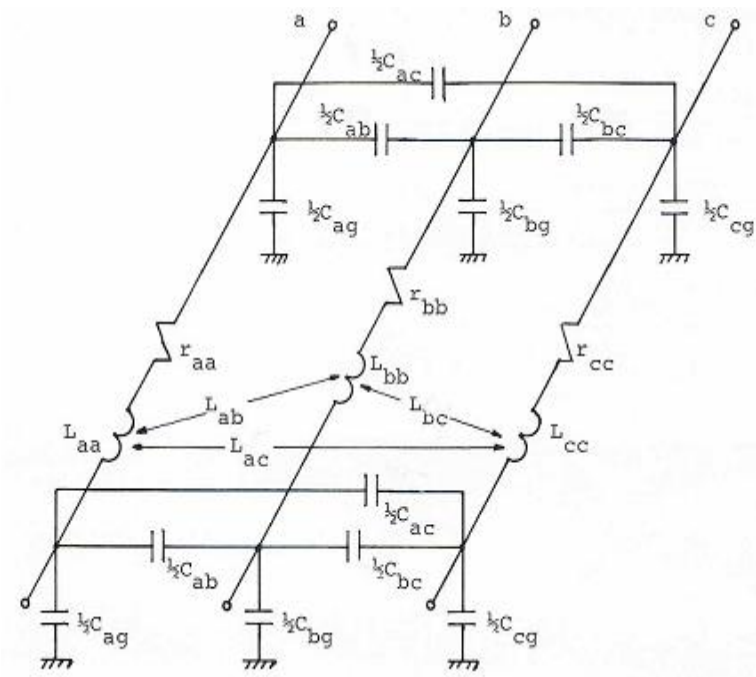

Figure (2): Transmission line equivalent PI-circuit. 


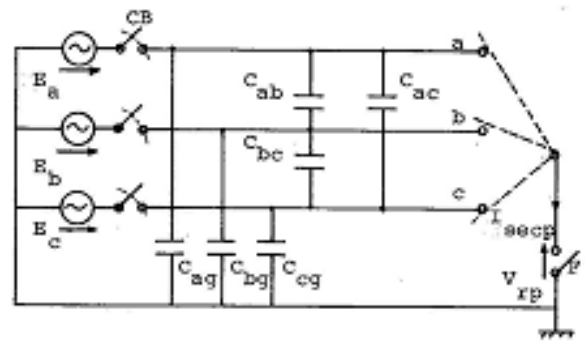

Figure (3): Equivalent lumped capacitance, 3-phase system.

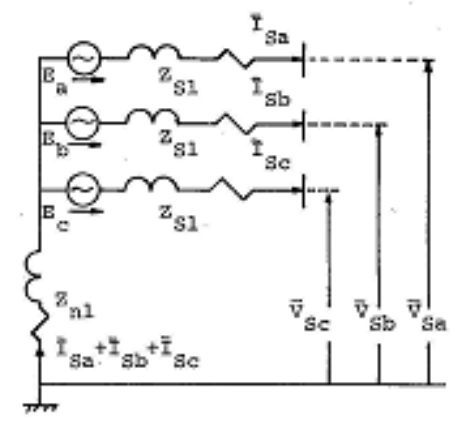

Figure (4): Source network model.

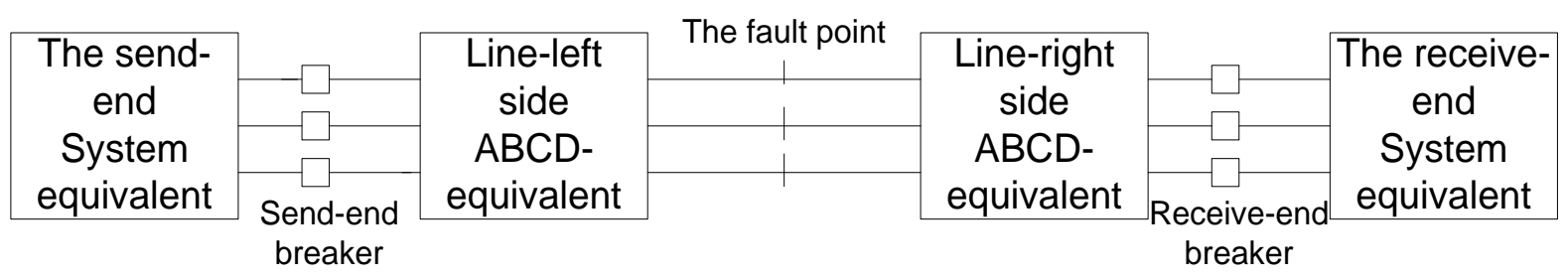

Figure (5): System model block-Normal operating state.

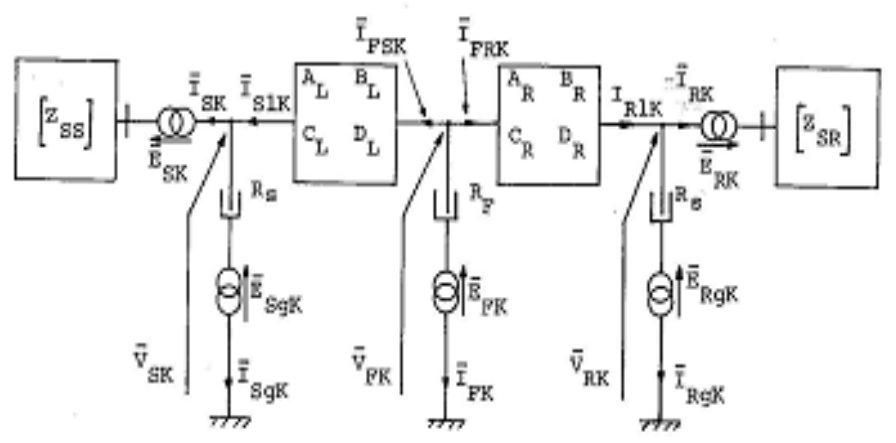

Figure (6): Frequency domain superimposed system model. 


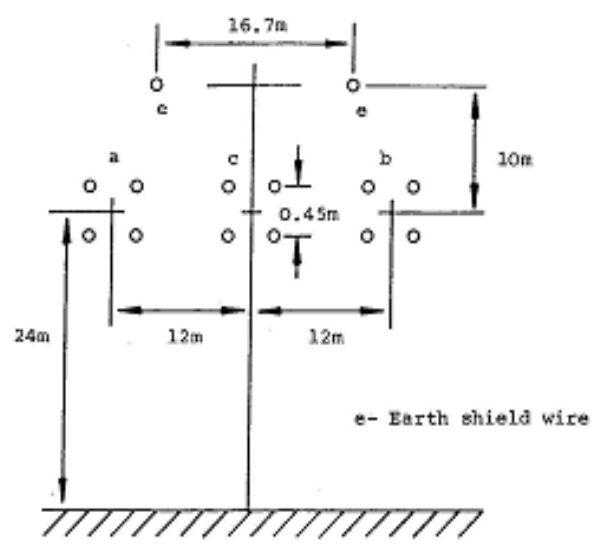

Figure (7): $500 \mathrm{kV}$ horizontal line construction.
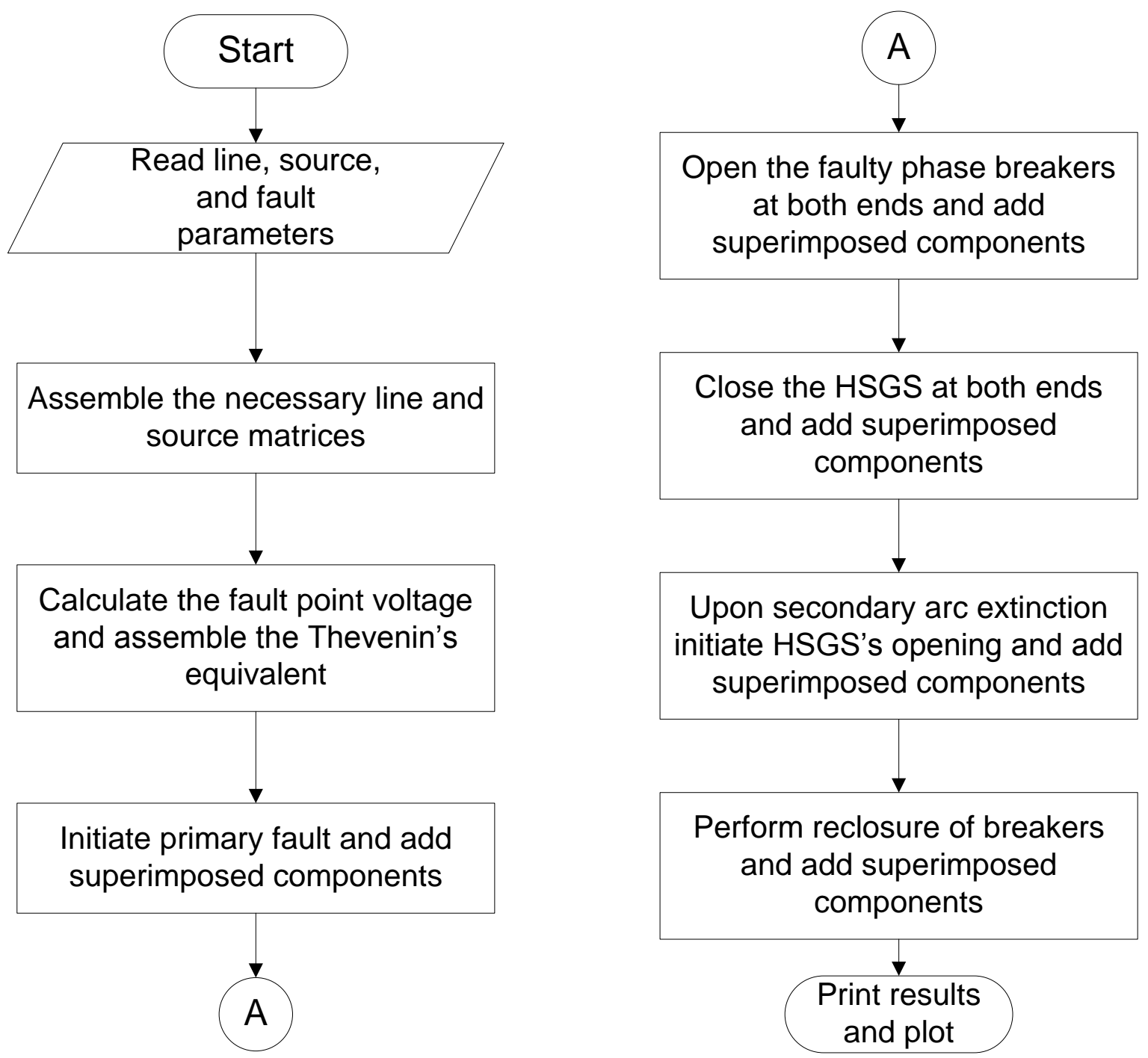

Figure (8): Simulation process flowchart. 

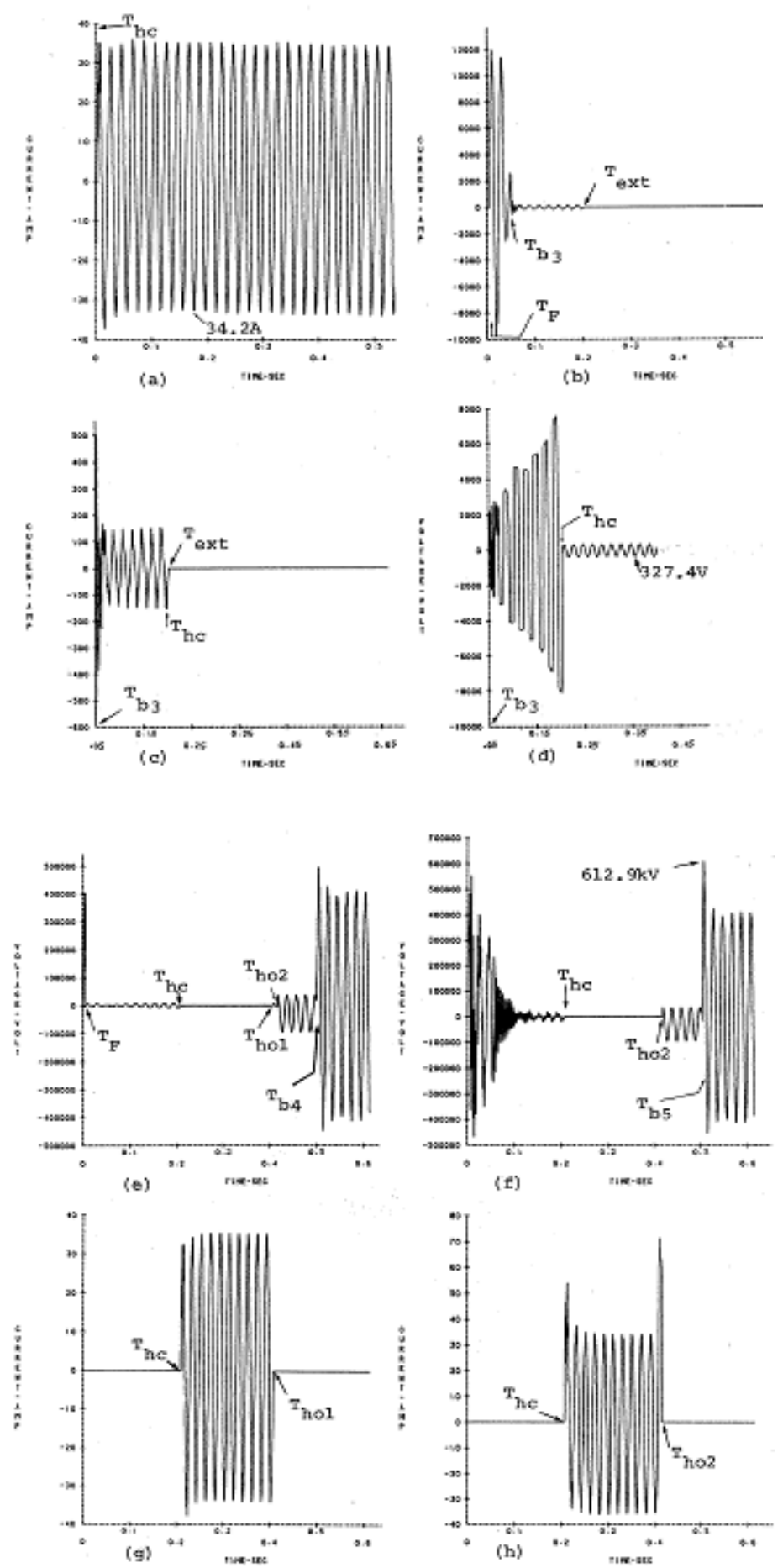

Figure (9): Fault at sending-end; No-load condition; Phase-a to earth fault a- Secondary arc current $\left(\mathrm{R}_{\mathrm{f}}=0.5 \Omega\right)$, b- Fault path current, c- Secondary arc current, d- Secondary arc voltage, e- Fault-point voltage, f- "a"-earth voltage at receive end, g- Sending end HSGS current, h- Receiving end HSGS current.

Line length $=300 \mathrm{~km}$, Short circuit level (both sides) $=5 \mathrm{GVA}, \mathrm{V}_{\mathrm{S}} / \mathrm{V}_{\mathrm{R}}=1.0\left\llcorner 0^{\circ}, \mathrm{T}_{\mathrm{F}}=5 \mathrm{msec}\right.$, $\mathrm{T}_{\mathrm{b} 2}=30.4 \mathrm{msec}$ (after fault), $\mathrm{T}_{\mathrm{b} 3}=49.6 \mathrm{msec}$ (a.f.), $\mathrm{T}_{\mathrm{hc}}=202 \mathrm{msec}$ (a.f.), $\mathrm{T}_{\mathrm{ho} 1}=402.4 \mathrm{msec}$ (a.f.), $\mathrm{T}_{\mathrm{ho} 2}=412.4 \mathrm{msec}$ (a.f.), $\mathrm{T}_{\mathrm{b} 4}=495.2 \mathrm{msec}$ (a.f.), $\mathrm{T}_{\mathrm{b} 5}=501.6 \mathrm{msec}$ (a.f.), $\mathrm{T}_{\mathrm{ext}}=154 \mathrm{msec}$. 

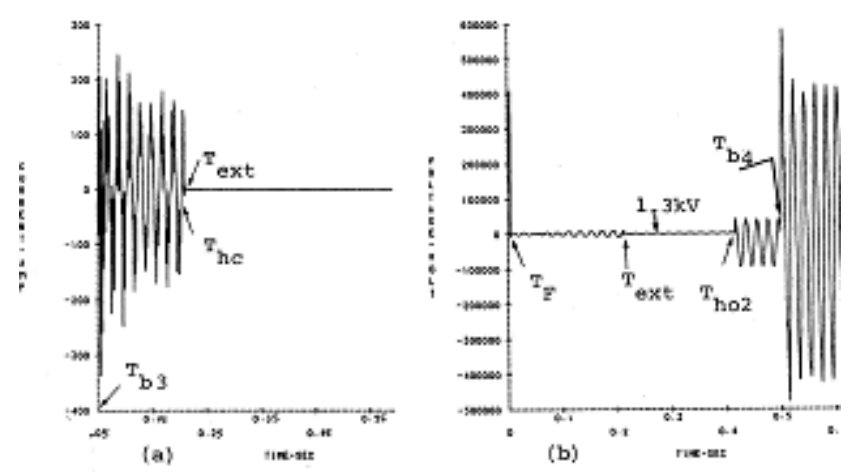

Figure (10): Mid-point fault; No-load condition; Phase-a to earth fault a- Secondary arc current, b- Fault-point voltage to earth. Line length $=300 \mathrm{~km}$, Short circuit level (both sides) $=5 \mathrm{GVA}, \mathrm{V}_{\mathrm{S}} / \mathrm{V}_{\mathrm{R}}=1.0\left\llcorner 0^{\circ}, \mathrm{T}_{\mathrm{F}}=5 \mathrm{msec}, \mathrm{T}_{\mathrm{b} 3}=50 \mathrm{msec}\right.$ (after fault), $\mathrm{T}_{\mathrm{hc}}=206.4$ $\operatorname{msec}$ (a.f.), $T_{h o 2}=412 \mathrm{msec}$ (a.f.), $\mathrm{T}_{\mathrm{b} 4}=495.2 \mathrm{msec}$ (a.f.), $\mathrm{T}_{\mathrm{ext}}=156.6 \mathrm{msec}$.
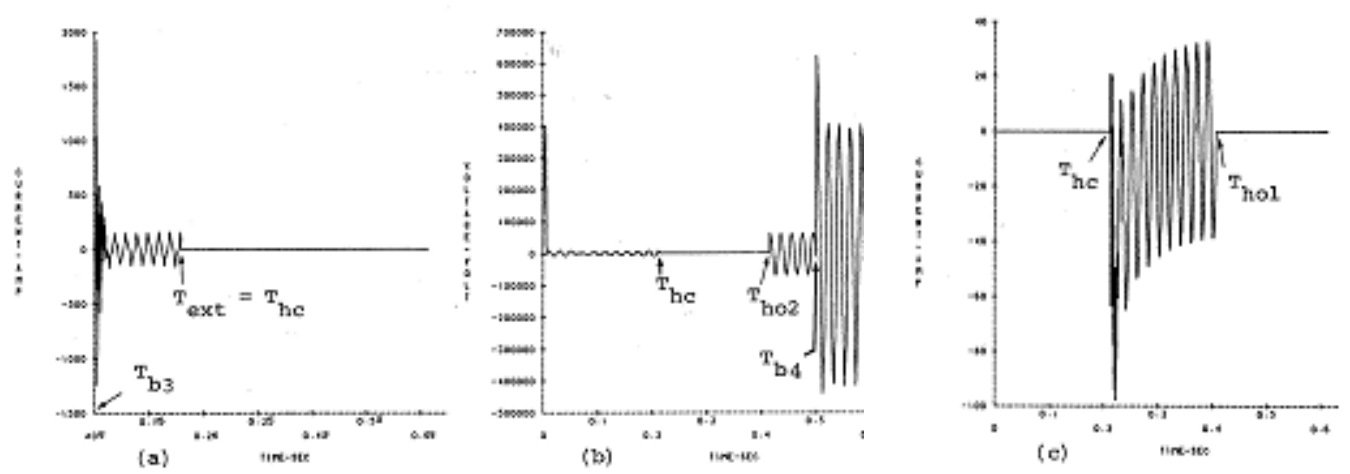

Figure (11): Effect of source capacity; Fault at receiving end; Phase-a to earth fault a- Secondary arc current, b- Fault-point voltage to earth, c- Send end HSGS current. Line length $=300 \mathrm{~km}$, Short circuit levels $=5 \mathrm{GVA}$, and $10 \mathrm{GVA}, \mathrm{V}_{\mathrm{S}} / \mathrm{V}_{\mathrm{R}}=1.0\left\llcorner 0^{\circ}, \mathrm{T}_{\mathrm{b} 3}=50 \mathrm{msec}\right.$ (after fault), $\mathrm{T}_{\mathrm{hc}}=207.2 \mathrm{msec}$ (a.f.), $\mathrm{T}_{\mathrm{hol}}=402 \mathrm{msec}$ (a.f.), $\mathrm{T}_{\mathrm{ho} 2}=412 \mathrm{msec}$ (a.f.), $\mathrm{T}_{\mathrm{b} 4}=495.2 \mathrm{msec}$ (a.f.), $\mathrm{T}_{\mathrm{ext}}=157.2 \mathrm{msec}, \mathrm{T}_{\mathrm{F}}=5 \mathrm{msec}$. 


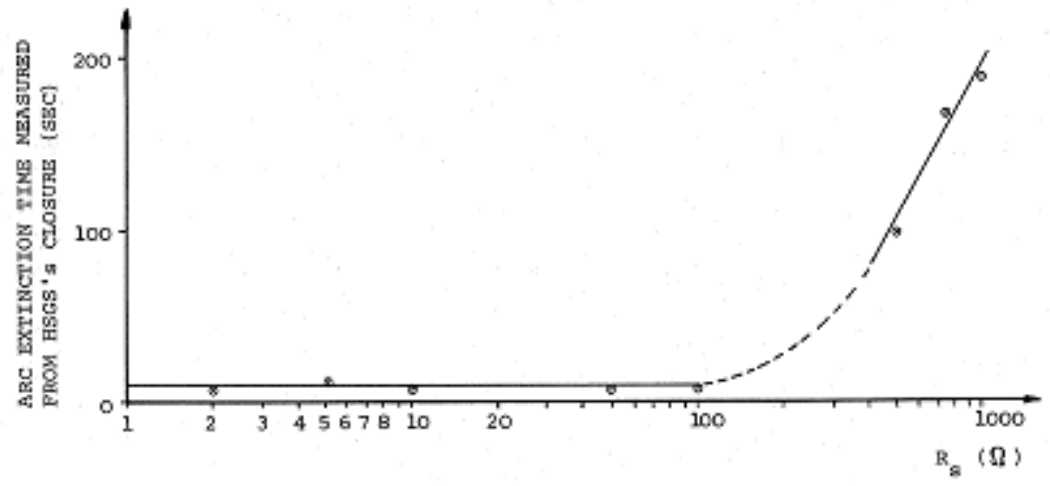

Figure (12): Variation of the arc extinction time with the HSGS resistance (Mid-point fault on phase-a). 


\title{
اطفاء القوس الكهريائي الثانوي في منظومات الجها العالي باستخدام مفاتيح تأريض
}

\author{
قيس متي الياس، وفاء فرج طوبيا \\ قسم الهندسة الكهربائية، الجامعة التكنولوجية، العراق
}

\section{الخلاصة}

تتسبب منظومات النقل ذات الجهد العالي (EHV) بحدوث حالة قوس كهربائي ثانوي مطولة بعد معالجة خطأ

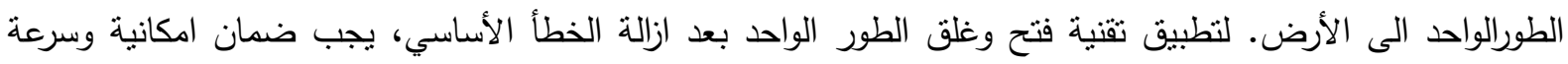
انطفاء القوس الكهربائي الثانوي بوقت قصير • خلال البضع عقود الماضية, تم عرض و تطبيق عدة تقنيات لضمان انطفاء القوس الكهربائي الثانوي بسرعة. احدى هذه التقنيات تضمنت استخدام مفاتيح التأريض السريعة (HSGS's). تأريض الطور المخطوء في نهايتي خط النقل بعد معالجة الخطأ الأساسي بواسطة قواطع دورة النهايات للخط. الفائدة

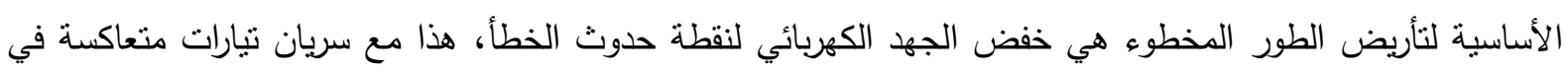

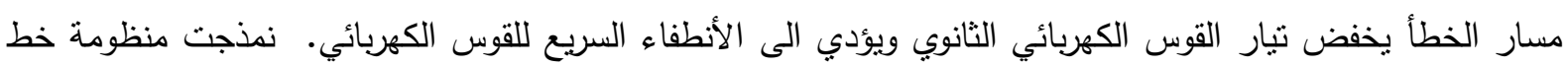

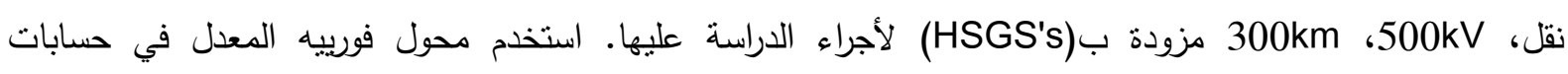

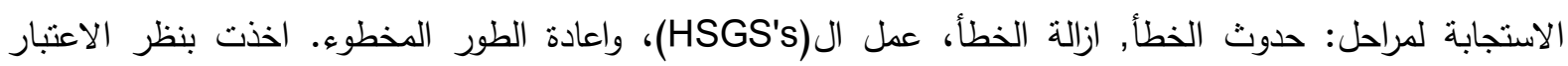
الخواص اللاخطية للقوس الكهبائي الثانوي. عرضت النتائج الحسابية للمنظومة اعلاه التحسن الكبير لاداء تثقنية الفتح والغلق للطور الواحد مع استخدام ال(HSGS'). 